\title{
Elementary Teachers' Views on Mind Mapping
}

\author{
Özgül Keleş \\ Faculty of Education, Aksaray University \\ Merkez Kampus, 68100, Aksaray, Turkey \\ Tel: 90-382-288-2257Ｅ-mail: ozgulkeles@gmail.com
}

Received: January 3, 2012 Accepted: February 21, 2012 Published: March 11, 2012

doi:10.5296/ije.v4i1.1327 URL: http://dx.doi.org/10.5296/ije.v4i1.1327

\begin{abstract}
The purpose of this study was investigating elementary teachers' views on mind mapping by using interviews. In this line, the study group of the research was composed of 24 elementary teachers experience periods in their job between two and 21 who were enrolled in a "Teaching Thinking Science Consulting Course". In the implementation phase of the study, the teachers were primarily instructed about the application of the mind mapping technique. In the interviews open-ended six questions were asked to teachers about mind mapping and the use of this technique in the classroom. Interviews were analyzed using qualitative research methods. Results showed that using mind mappings in instruction helps teachers improve their instruction, planning and evaluating lessons and makes the lecture more entertaining. The technique can be suggested to extend by analyzing its relation with different variables like different lessons and participants.
\end{abstract}

Keywords: Elementary Teachers' Views, Mind mapping, Turkey 


\section{Introduction}

Elementary level science and technology program was developed based on constructivist approach. For students to achieve the objectives set by the program, student-centered teaching methods and techniques should be employed. Because of this teachers utilize various instructional strategies to be effective in assisting students' learning. One of the visual techniques that are used with the stated objectives is mind mapping. According to Zhao (2003) teachers can understand if students understood the subject and if they could construct an appropriate structure for the new information by examining their mind maps. Mind mapping is a note-taking, organizational technique, which allows individuals to "organize facts and thoughts" (Buzan, 2002) in a map format containing a "central image, main themes radiating from the central image, branches with key images and key words, plus branches forming a connected nodal structure" (Buzan, 1993). In addition, the mind map helps students to assimilate new information, to think and to develop their conceptual schema. Mind mapping is a technique which enhances creativity and promotes individuals' learning (Mento, Martinelli \& Jones, 1999). They assure individuals to recall knowledge and to show the relations between different thoughts and concepts (Evrekli, Balım \& Inel, 2009; Buzan, 2005). During teaching and learning, a mind map also helps teachers to explain why they are focusing on a particular aspect of a topic. From the mind maps that students make, teachers may learn whether their students understand the topic and whether the student is able to organize and construct a suitable structure for that knowledge (Zhao, 2003).

Recent years, studies of mind mapping have been conducted with various age groups in the literature. Positive and negative effects have been encountered. Evrekli et al. (2009) found that according to science teacher candidates, mind mapping can be used in constructive science and technology effectively. To Farrand, Hussain, and Hennessy (2002) "Mind maps provide an effective study technique when applied to written material". Taliaferro (1998) determined that students enjoyed the mind-mapping exercise. Negative results of the study were students' level of cognitive development. Students were not able to "think abstractly". Goodnough and Woods (2002) performed a qualitative, interpretive case study on two fifth-grade classes and two sixth-grade classes. There were many effects of this study. Students' perceptions of mind mapping were "fun, interesting, and a motivating approach to learning". In addition, students preferred to use mind mapping in an individual situation rather than a group situation because they could express their own ideas for their own meaning. Williams (1999) stated that mind mapping provided students with an opportunity to improve their learning. According to this study, the mind-mapping technique, as confirmed by other studies, "is helpful as a study aid and helps learners understand and recall information better". Negative outcomes of the study involved adults who found this strategy to be "uncomfortable to use" (Williams, 1999). Their reasoning was because it lacked structure and required spontaneity. Time and practice were required for adults to feel comfortable with the strategy.

When the features of mind maps are taken into consideration, it is proposed that using mind maps in the different lessons might be effective tool. Furthermore, views of the elementary teachers' using mind maps in their lessons can provide feedback for the investigators about 
utility, uses of learning environments and limits of using mind maps. Thus, it was needed to make a search intended to investigate elementary teachers' views on mind mapping by using interviews.

\section{Research Methods}

The study group of the research was composed of 24 elementary teachers (18 females; six males) experience periods in their job between two and 21 who were enrolled in a "Teaching Thinking Science Consulting Course". In the implementation phase of the study, the teachers were primarily instructed about the application of the mind mapping technique. Firstly, mind maps were presented in details to the teachers participating in the study. Then, a mind map was prepared with the participants stating one day's plan. After preparing sample map, each participant was asked for to prepare a mind map presenting himself /herself individually. Participants were enabled to analyze each other's mind maps by presenting the studies carried out on mind maps on the board. In the interviews open-ended six questions were asked to teachers about mind mapping and the use of this technique in the classroom. Interviews were analyzed using qualitative research methods.

\section{Analysis of Results}

This part includes the findings of the research and interpretations of the findings. The first open ended question intended for identifying views of elementary teachers relating to applications of mind maps was: "What do you think about mind maps? Please explain."

The percent -frequency rates relating to answers and categories of their thoughts given to this open ended question by the elementary teachers are given place in Table 1.

Table 1. Views of Elementary Teachers Relating to the First Open Ended Question

\begin{tabular}{|c|c|c|c|}
\hline \multicolumn{4}{|c|}{ What do you think about mind maps? Please explain. } \\
\hline Categories & $\mathrm{f}$ & $\%$ & Sample Expressions \\
\hline It is a technique suitable for 1-3 class levels. & 3 & 7 & \\
\hline It is a plan determining ways to solution. & 2 & 4 & "It is a technique that is quite creative and \\
\hline $\begin{array}{l}\text { It is a technique that can be applied freely, } \\
\text { is easy to be prepared and fertile. }\end{array}$ & 7 & 15 & permanent in learning." \\
\hline It makes comprehension easy. & 3 & 7 & "I believe that mind mapping is a useful, \\
\hline It enables visual learning. & 4 & 9 & enjoyable and practicable technique that \\
\hline It improves creativity. & 4 & 9 & can be used in making sense of, \\
\hline $\begin{array}{l}\text { It is an enjoyable, interesting and a colorful } \\
\text { study. }\end{array}$ & 7 & & $\begin{array}{l}\text { summarizing and classifying of the data } \\
\text { and in which we can use pictures and act }\end{array}$ \\
\hline $\begin{array}{l}\text { It is effective in enabling data's } \\
\text { permanence. }\end{array}$ & 6 & 13 & freely and show our creativity." \\
\hline $\begin{array}{l}\text { It enables data's being organized and } \\
\text { classified. }\end{array}$ & 3 & 7 & \\
\hline It is useful in data's being summarized. & 3 & 7 & \\
\hline $\begin{array}{l}\text { It enables constituting mental schemas of } \\
\text { the learned. }\end{array}$ & 3 & 7 & \\
\hline
\end{tabular}

For the purpose of determining the opinions of teachers concerning mind mapping 
applications the following open ended question was inquired: "Do you think that mind maps are applicable in the learning environment? Why? "

The percent-frequency rates relating to answers given to this open ended question by the elementary teachers are given place in Table 2.

Table 2. Views of Elementary Teachers Relating to the Second Open Ended Question

\begin{tabular}{|c|c|c|c|}
\hline \multicolumn{4}{|c|}{ Do you think that mind maps are applicable in the learning environment? Why? } \\
\hline Categories & $\mathrm{f}$ & $\%$ & Sample Expressions \\
\hline It makes learning permanent. & 4 & 14 & \\
\hline It makes data visual. & 6 & 21 & I think that it is applicable. Since it makes \\
\hline It makes data systematic. & 1 & 4 & data visual, it provides learning to be \\
\hline $\begin{array}{l}\text { It is a technique that can be utilized easily in } \\
\text { learning environments in which oral and }\end{array}$ & 4 & 14 & permanent.' \\
\hline $\begin{array}{l}\text { visual expressions can be used together. } \\
\text { It enables coding of the data learned in } \\
\text { minds. }\end{array}$ & 1 & 4 & $\begin{array}{l}\text { "It can be applied easily. Togetherness of } \\
\text { pencil, paper and imagination is enough." }\end{array}$ \\
\hline It provides pencil-paper and imagination. & 7 & 25 & "I believe that students will enjoy a lot as \\
\hline It can be use planning of a day and a course. & 1 & 4 & in mind maps students can act freely, can \\
\hline $\begin{array}{l}\text { It is a study that will appeal students as they } \\
\text { will feel themselves free and they can draw } \\
\text { pictures by using colors. }\end{array}$ & 4 & 14 & draw pictures, and they can use colors." \\
\hline
\end{tabular}

At the end of the analyses of the second open ended question, 24 participants expressed that it can be definitely applicable. For the purpose of determining the opinions of teachers concerning mind mapping applications the following open ended question was inquired: "In which step of your lessons do you plan to use mind maps? Why?"

The percent-frequency rates relating to answers given to this open ended question by the elementary teachers are given place in Table 3.

Table 3. Views of Elementary Teachers Relating to the Third Open Ended Question

\begin{tabular}{|c|c|c|c|}
\hline \multicolumn{4}{|c|}{ In which step of your lessons do you plan to use mind maps? Why? } \\
\hline Categories & $\mathrm{f}$ & $\%$ & Sample Expressions \\
\hline In searching pre-knowledge & 21 & 40 & "I believe that I can use it to summarize the \\
\hline In evaluating teaching & 15 & 30 & $\begin{array}{l}\text { course in starting and after the course." } \\
\text { "In introduction part, I use it to determine }\end{array}$ \\
\hline In getting feedback & 4 & 8 & being ready, to comprehend the things learned \\
\hline In measuring their levels of being ready & 3 & 6 & and in conclusion part to get feedback about \\
\hline In summarizing the course & 3 & 6 & the deficiencies." \\
\hline $\begin{array}{l}\text { In determining whether conceptual learning is } \\
\text { realized or not }\end{array}$ & 2 & 4 & $\begin{array}{l}\text { "I had some studies in self knowledge with } \\
\text { disabled children and in concept teaching with }\end{array}$ \\
\hline In planning courses and daily life & 1 & 2 & autistic children. ", \\
\hline In making courses enjoyable & 1 & 2 & "Before the course, I use it in order to \\
\hline With autistic children in teaching concepts & 1 & 2 & $\begin{array}{l}\text { determine pre-knowledge for evaluating } \\
\text { students' being ready for the course and in } \\
\text { evaluating teaching." }\end{array}$ \\
\hline
\end{tabular}


All the participants expressed that they will use it in searching pre-knowledge, in summarizing relevant subject and evaluating. For the purpose of determining the opinions of teachers concerning mind mapping applications the following open ended question was inquired: "Do you prefer using the mind maps prepared by you or your students in your courses? Why?"

The percent -frequency rates relating to answers given to this open ended question by the elementary teachers are given place in Table 4.

Table 4. Views of Elementary Teachers Relating to the Fourth Open Ended Question

Do you prefer using the mind maps prepared by you or your students in your courses? Why?

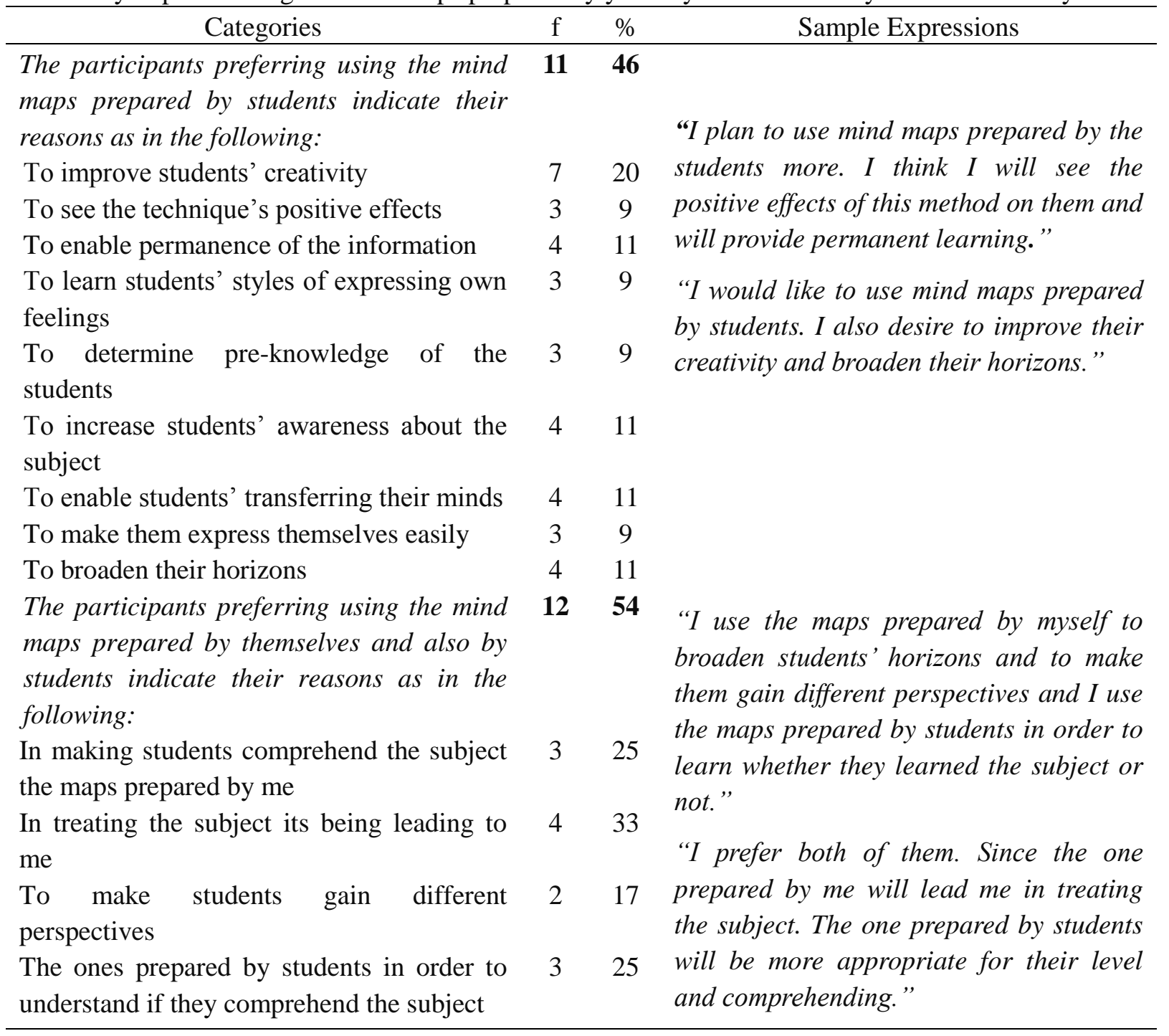

11 participants preferred using the ones prepared by students when 12 ones preferred both the mind maps prepared by themselves and the students in accordance with the content of the subject. For the purpose of determining the opinions of teachers concerning mind mapping applications the following open ended question was inquired: "In which points do you think your students and you will have difficulties in preparing mind maps? Why?"

The percent-frequency rates relating to answers given to this open ended question by the 
elementary teachers are given place in Table 5.

Table 5. Views of Elementary Teachers Relating to the Fifth Open Ended Question

In which points do you think your students and you will have difficulties in preparing mind maps?

\begin{tabular}{|c|c|c|c|}
\hline \multicolumn{4}{|c|}{ Why? } \\
\hline Categories & $\mathrm{f}$ & $\%$ & Sample Expressions \\
\hline In the stage of drawing visuals & 8 & 29.6 & \\
\hline $\begin{array}{l}\text { In the stage of planning and making } \\
\text { details }\end{array}$ & 4 & 14.8 & developed in students' drawings visual \\
\hline In classifying general and specific concepts & 2 & 7.4 & images ana symoollzallon, there may be \\
\hline In the stage of correlating & 6 & 22.2 & some aljucumles. \\
\hline No difficulty will be seen. & 7 & 25.9 & $\begin{array}{l}\text { "Students may have difficulties in } \\
\text { classifying general and more specific } \\
\text { concepts." }\end{array}$ \\
\hline & & & $\begin{array}{l}\text { "I do not think that students will have } \\
\text { difficulties in the stage of preparing when } \\
\text { they are made comprehend what mind } \\
\text { maps are and their function. }\end{array}$ \\
\hline
\end{tabular}

In Table 5, seven participants indicated that no difficulty will be exposed and 17 participants expressed that in some points there may be some troubles. For the purpose of determining the opinions of teachers concerning mind mapping applications the following open ended question was inquired: "Which one do you think more useable (concept or mind maps) when taking into consideration learning environment, learning tools, teaching program, course instruments? Why?"

The percent-frequency rates relating to answers given to this open ended question by the elementary teachers are given place in Table 6.

Table 6. Views of Elementary Teachers Relating to the Sixth Open Ended Question

\begin{tabular}{|c|c|c|c|}
\hline \multicolumn{4}{|c|}{$\begin{array}{l}\text { Which one do you think more useable (concept or mind maps) when taking into consideration } \\
\text { learning environment, learning tools, teaching program, course instruments? Why? }\end{array}$} \\
\hline Categories & $\mathrm{f}$ & $\%$ & Sample Expressions \\
\hline Mind maps are more useable. & 14 & 58 & $\begin{array}{l}\text { "Mind maps are more useable as they give } \\
\text { students freedom of expressing themselves, } \\
\text { improves creativity, have less rules and } \\
\text { develop level of remembering by appealing } \\
\text { to visual intelligence and it increases the } \\
\text { interest to the course." }\end{array}$ \\
\hline Concept maps are more useable. & 3 & 12 & $\begin{array}{l}\text { "Concept map is a more suitable } \\
\text { technique in expressing theoretical } \\
\text { information." }\end{array}$ \\
\hline Both of them are useable. & 7 & 30 & $\begin{array}{l}\text { "I believe that in the first grades of } \\
\text { primary education mind maps and in the } \\
\text { preceding years mind maps should be used } \\
\text { in accordance with the age, student level } \\
\text { and subject content." }\end{array}$ \\
\hline
\end{tabular}




\section{Conclusions}

The data gathered indicated that all the teachers participated in the study believe that mind maps are effective tools in learning and improving students' creativity and in providing permanent learning. Participants emphasized that it is a technique that appeals visual intelligence, gives students chance to express themselves freely and that is easily applicable. They also expressed that this technique can be applied in all grades of learning and in early years of primary education it is more appropriate to use mind maps than concept maps. Among the difficulties in application of this technique, drawing pictures and correlating concepts can be counted. Relevant literature studies support these findings (Balım, Aydın \& Evrekli, 2006; Treviño, 2005; Goodnough \&Woods, 2002; Williams, 1999; Taliaferro, 1998)

Graphic organizers assist learning by providing an opportunity for visual stimuli, assessment, checking understanding, elaboration, note taking, summarizing, illustrating sequence of events, and other creative ways of instruction (Gregory \& Chapman, 2002; Treviño, 2005; Bromley, Irwin-DeVitis \& Modlo, 1995). There are studies showing that mind maps contribute to longer retention of the information through mind maps (Akınoğlu \& Yaşar, 2007; Buzan, 2005); help students to see the connections among the pieces of information (Evrekli \& Balım, 2010; Evrekli, Balım \& Inel, 2009); in light of these findings, mind maps are thought to be useful for teachers while teaching science concepts.

Mind mapping improves students' skills of thinking and reveals their creativity by using different colors and shapes and affects them positively. Teachers can help students to improve thinking skills and creativity by using mind mapping together with the other techniques in accordance with the philosophy of constructivist approach. An important implication of this study is that there is a need for teachers to know how to teach mind map construction and to associate the mind maps into their lessons. The present study is limited to the elementary teachers. In order to extend the use of mind mapping technique, this technique can be offered to teachers from different branches.

\section{References}

Akınoğlu, O., \& Yaşar, Z. (2007). The effects of note taking in science education through the mind mapping technique on students' attitudes, academic achievement and concept learning. Journal of Baltic Science Education, 6(3), 3443.

Balım, A. G., Aydın, G., \& Evrekli, E. (2006, April). Fen ve teknoloji öğretiminde zihin haritalarl ve kavram haritalart kullanmanın önemi. Presented at the VI. International Educational Technologies Conference, Famagusta, Turkish Republic of Northern Cyprus.

Bromley, K., Irwin-DeVitis, L., \& Modlo, M. (1995). Graphic organizers: Visual strategies for active learners. New York, NY: Scholastic Professional Books.

Buzan, T. (2005). Mind map: The ultimate thinking tool. London: Thorsons.

Buzan, T. (2002). How to mind map. London: Thorsons.

Buzan, T. (1993). The mind map book: How to use radiant thinking to maximize your brain's 
untapped potential. New York, NY: Penguin Group.

Evrekli, E., \& Balım, A. G. (2010). Fen ve teknoloji öğretiminde zihin haritası ve kavram karikatürü kullanımının öğrencilerin akademik başarıları ve sorgulayıcı öğrenme becerileri algılarına etkisi. Batı Anadolu Eğitim Bilimleri Dergisi (BAED), 1(2), 76-98. Retrieved from http://web.deu.edu.tr/baed/giris/baed/sayi_2.pdf

Evrekli, E., Balım, A.G., \& Inel, D. (2009). Mind mapping applications in special teaching methods courses for science teacher candidates and teacher candidates' opinions concerning the applications. Procedia Social and Behavioral Sciences, 1, 2274-2279. http://dx.doi.org/10.1016/j.sbspro.2009.01.400

Farrand, P., Hussain, F., \& Hennessy, E. (2002). The efficacy of the 'mind map' study technique. Medical Education, 426-431. http://dx.doi.org/10.1046/j.1365-2923.2002.01205.x

Goodnough, K., \& Woods, R. (2002, April). Student and teacher perceptions of mind mapping: A middle school case study. Paper presented at the American Educational Research Association Annual Meeting, New Orleans, LA. Retrieved from http://faculty.ksu.edu.sa/aljarf/Research\%20Library/Mind-mapping/84.pdf

Gregory, G.H., \& Chapman, C. (2002). Differentiated instructional strategies: One size doesn't fit all. Thousand Oaks, CA: Corwin Press, Inc.

Mento, A. J., Martinelli, P., \& Jones, R. M. (1999). Mind mapping in executive education: Applications and outcomes. Journal of Management Development. 18(4). 390-416. http://dx.doi.org/10.1108/02621719910265577

Taliaferro, M. (1998). Mindmapping effects on sixth grade students' recall ability. Unpublished master's thesis, Mercer University, Atlanta, Georgia.

Treviño, C. (2005). Mind mapping and outlining: Comparing two types of graphic organizers for learning seventh-grade life science. Unpublished $\mathrm{PhD}$ thesis, Texas Tech University, Texas, USA.

Williams, M.H. (1999). The effects of a brain-based learning strategy, mind mapping, on achievement of adults in a training environment with consideration to learning styles and brain hemisphericity. Unpublished doctoral dissertation, University of North Texas, Dissertation Abstracts International, 60, 1525.

Zhao, Y. (2003). The use of a constructivist teaching model in environmental science at Beijing Normal University. The China Papers, 2, 78-83. Retrieved from http://science.uniserve.edu.au/pubs/china/vol2/yezhao.pdf

\section{Copyright Disclaimer}

Copyright reserved by the author(s).

This article is an open-access article distributed under the terms and conditions of the Creative Commons Attribution license (http://creativecommons.org/licenses/by/3.0/). 